\title{
Př́ínos monoski pro osoby s tělesným postižením - vliv na kvalitu života
}

\section{Benefits of Monoski for People with Disabilities - Impact on Quality of Life}

\author{
Růžičková, K. ${ }^{1}$, Růžička, I. ${ }^{2}$, Francová, L. ${ }^{2}$, Culková, D. ${ }^{2}$
}

\begin{abstract}
Abstrakt
Pohybové aktivity jedinců se zdravotním postižením přispívají ke zlepšení úrovně motoriky a kladně ovlivňují psychosociální oblasti života. Zimní aktivita monoski u nás v současnosti zaznamenává velký rozvoj. Cílem výzkumu bylo zjistit vliv lyžování na monoski na kvalitu života prostřednictvím zpracování kvantitativní dat získaných dotazníkovým šetřením. Výzkumný soubor tvořilo 60 osob - účastníků kurzů lyžování na monoski v Centru handicapovaných lyžařo v Janských Lázních. Z výsledků šetření vyplývá, že lyžování na monoski u 76,6 \% respondentů pozitivně ovlivňuje kvalitu jejich života. Mezi tři klíčové přínosy respondenti uvedli: 1) zuýšení radosti ze života a příležitost $k$ zábavě, 2) zpestření života a pocity vzrušení a 3) navázání vřelých vztahů s druhými. Z výsledků výzkumu také vyplývá, že z cúlové skupiny osob po úrazu (21 osob) se 81 \% díky monoski k lyžování opět navrací a aktivita tak pomáhá k udržení úrovně kvality předchozího života. Výsledky naznačují, že pohyb na monoski přispívá ke zvýšení kvality života, a to nejen z hlediska možnosti realizace vlastní pohybové činnosti, ale i pro zlepšení psychického zdraví, kontaktu s druhými a věnování se lyžováníi v poúrazovém stavu.
\end{abstract}

\section{Klíčová slova}

Pohyb, osoby se zdravotním postižením, lyžování, monoski, kvalita života.

\section{Abstract}

Physical activities of individuals with disabilities help to improve motor skills levels and positively affect the psychosocial areas of life. The monoski winter activity is currently experiencing a great development in our country. The aim of the research was to determine the effect of the monoski skiing on the quality of life through the processing of quantitative data obtained by a questionnaire survey. The research sample consisted of 60 persons - participants of a monoski skiing course in the Centre of disables skiers in Janské Lázně in the Czech Republic. The results of the survey show that monoskiing in 76,6\% of respondents has a positive effect on their quality of life. Among the three benefits, the respondents mentioned:1) increased joy of life and opportunity to have fun, 2) diversified life and feelings of excitement and 3) establishing warm relationships with others. The results of the research also show that from the target group of people after an accident (21 persons), 81\% return thanks to mononski for skiing and the activity thus helps to maintain the level of quality of the previous life. The results suggest that moving on a monoski contributes to an increase in the quality of life, not only in terms of the possibility of implementing one's own physical activity, but also for improving mental health, contact with others and to be engaged in skiing even in post-traumatic conditions.

\section{Keywords}

Movement, persons with disabilities, skiing, monoski, quality of life

1 Ústav primární, preprimární a speciální pedagogiky, Pedagogická fakulta, Univerzita Hradec Králové 2 Katedra tělesné výchovy a sportu, Pedagogická fakulta, Univerzita Hradec Králové 


\section{Teoretická východiska}

Statistiky uvádějí, že v České republice žije 1151900 osob se zdravotní postižením, což představuje $11 \%$ tuzemské populace, přičemž největší zastoupení mají osoby s postižením tělesným tvořící 72,1 \% v rámci celkového počtu [3]. Významným dokumentem, který přispěl k rozvoji pohybové aktivnosti osob se zdravotním postižením, byla Úmluva o právech osob se zdravotním postižením. V dokumentu je uveden cíl umožnit osobám se zdravotním postižením podílet se na rovnoprávném základě s ostatními, na rekreační, zájmové či sportovní činnosti, jak uvádí [18]. V článku 8 Charty práv osob s tělesným postižením je uvedeno, že každá osoba s tělesným postižením má právo na zajištění svého pohodlí a spokojeného života [23, 24]. Osoby se zdravotním postižením mají stejná práva na plnohodnotný a rovnocenný život jako intaktní populace.

Pohybová aktivita je důležitou součástí života současné populace, všech věkových kategorií, úrovní a oblastí. Neodmyslitelně se důležitost pravidelného pohybu vztahuje k osobám se zdravotním postižením, kde zapojení do vhodných aktivit může přinášet další významné benefity, ve srovnání se sportující intaktní populací.

\section{Význam pohybu pro osoby se zdravotním postižením}

Pohyb obecně přispívá k možnosti žít plnohodnotný život, který zahrnuje aktivní zapojení do rodinného života, pracovního procesu a společenských funkcí. Při zaměření na aktivní pohyb osob se zdravotním postižením možno stanovit určité cíle. Za obecný cíl považujeme rozvíjení základních pohybových schopností a dovedností, což jsou obratnost, síla, vytrvalost, udržení rovnováhy, prostorová orientace, rychlost reakce, celkově manuální zručnost, koordinačně zvládnutá jízda na vozíku, ale také zvládnutí hygienických návyků apod. Za další cíl lze považovat formování psychických vlastností (zvládání emocí, adaptace, vyrovnání se s konfliktem, předcházení civilizačním chorobám, podpora zdravého životního stylu a překonávání sociálních bariér. Zaměřením na tyto oblasti dochází k přijetí sociálních rolí a k navazování kontaktů v rámci intaktní populace [14].

Kvalita života osob se zdravotním postižením představují úroveň naplněných potřeb a požadavků i práv člověka s postižením směřující ke spokojenosti, komfortu, k životní pohodě a jistotě při podmínkách vážného a trvalého poškození zdraví či organizmu [12]. Při vymezení kvality života lze vycházet z Maslowovy pyramidy potřeb [22]. V této teorii je posuzován předpoklad, že naplnění základních fyziologických potřeb je východiskem k uspokojení potřeb návazných, jakými jsou bezpečí, pocit sounáležitosti, láska, sebeúcta a další. Propojení plnění potřeb je však oboustranné.

Světová zdravotnická organizace [37] uvádí čtyři oblasti, které zasahují do jednotlivých dimenzí lidského života, kterými jsou fyzické zdraví, psychické zdraví, sociální klima a prostředí. Snaha o vytvoření optimálního zdravého životního stylu ovlivňuje celkovou kvalitu života osob se zdravotním postižením, přičemž pravidelná pohybová aktivita pozitivně ovlivňuje zdravotní, psychické i sociální oblast:

Přiměřené provozování vhodné pohybové aktivity zajištuje u jedince s postižením zlepšování úrovně motoriky, držení těla, prostorové orientace a celkové koordinace. U osob s tělesným postižením je zdravotní význam pohybu spatřován ve zvyšování kloubního rozsahu a silové úrovně, vyrovnávání svalových dysbalancí, snižování svalových kontraktur a v kompenzaci jednostranné zátěže. Vhodnou a přiměřenou pohybovou aktivitu můžeme považovat za účinný prostředek proti svalové atrofii. Udržuje a rozvíjí celkovou fyzickou kondici osob se zdravotním postižením. To se projevuje především rozvojem svalové síly a vytrvalostní výkonnosti, což jsou důležité komponenty komplexních dovedností, které osobám s postižením umožňují vyrovnávat se s úkoly běžného každodenního života [2]. Sledováním pohybových možností a tím kvality života považuje [10] za základní součásti zdravotnických a medicínských intervencí.

Z hlediska psychologického významu pohyb pozitivně ovlivňuje celkové sebepojetí člověka. Aktivně působí na oblast zvyšování sebedůvěry, samostatnosti, pocitu vlastní hodnoty, povědomí o sebekázni a sebekontrole, přináší subjektivní pocity zdraví, síly a dostatku energie [2]. Dochází k formování psychických vlastností jedince, jakými jsou volní úsilí, schopnost koncentrace, zvládání emocí, adaptace a kooperace, vyrovnávání se s konfliktními situacemi, kompenzace pocitů méněcennosti[14]. Vliv na vnímání, vlastní pocity v souvislosti s pohybovými aktivitami a sportem potvrzují na základě svých výzkumů [31]. Lahtinen, Rintala a Malin [20] shrnují, že zapojení do pohybových aktivit vede ke zlepšení, zviditelnění, uznání a tím vyšší úrovni společenského postavení, které výrazně ovlivňuje psychický stav daného jedince. Vzniká propojení mezi psychikou a sociální oblastí.

Výrazný sociální význam pohybu můžeme spatřovat v překonávání sociálních bariér v životě osoby se zdravotním postižením. Jedinec s handicapem přijímá své sociální role, navazuje kontakty a nová 
přátelství s postiženými či „zdravými“ jedinci. Dochází k výměně zkušeností a informací. Prostřednictvím těchto vztahů se jedinec zapojuje do dalších společenských aktivit a nedochází k sociální izolaci. Kábele [14] pro oblast sportu uvádí: „....prokázalo se, že sportovní aktivity pozitivně ovlivňují plnohodnotné zapojení do společnosti, posilují rodinnou soudržnost a významně rozšiřují zónu sociálních kontaktů. Navíc sportovní úspěšnost vhodně kompenzuje pocity méněcennosti a životní zbytečnosti, poruchy seberealizace." Pozitivní vliv pravidelné pohybové aktivity v platformě výkonnostního sportu potvrdila Francová [6], která uvádí, že tréninkový program přináší pozitivní změny i do běžného života sportovce se zdravotním postižením. Významný vliv pohybové aktivnosti osob se zdravotním postižením spočívá v jejich začlenění do společenského života, tzv. integraci - nejvyšší stupeň socializace jedince, tedy jakési splynutí s okolím, rovnoprávné začlenění se do společnosti. Na tomto stupni jsou osoby se zdravotním postižením nezávislé a samostatné čili nepotřebují speciální přístupy svého okolí [25]. Jesenský [11] integraci chápe jako „stav soužití postižených a nepostižených při přijatelné míře konfliktnosti, jako stav vzájemné podmíněnosti vyjádřené slovy - jeden pro druhého“. V zásadě jde tedy o propojování skupiny osob se znevýhodněním se skupinou zdravých, mezi nimiž je odbourávána určitá segregační hranice. Vytváří se tak nový ucelený systém s hodnotami přetvořenými na základě obou skupin, míra integrace je však podmíněna mírou rovnocennosti postiženého [29].

Prožitek provázející pohybové aktivity vede k nárůstu sebehodnocení a sebedůvěry, hrdosti po výkonu, zlepšení sebekontroly, vědomí prospěšnosti z hlediska zdraví, úspěchu ve smyslu dosažení a zvládnutí pohybového úkolu [30]. Tyto hodnoty jsou u člověka s postižením velice oslabené a díky pohybové aktivnosti je lze snáze naplnit.

\section{Tělesné postižení a pohyb}

Dnešní společnost nabízí člověku s postižením mnoho prostředků, díky kterým mohou eliminovat svoje znevýhodnění a proživat tak plnohodnotný život. Jedním z nich je právě i pohybová aktivita. Pohyb je považován za významný a nezastupitelný faktor lidského rozvoje, který pozitivně ovlivňuje zdravotní, psychický a sociální stav jedince s postižením. Pravidelná aktivnost může pomoci vyrovnat se s nastalou situací, umožnit lepší kontakt se sociálním prostředím, zmírnit pocity méněcennosti a zbytečnosti a usnadnit návrat do života [21].

Tělesné postižení je příčinou určitého omezení samostatnosti [36]. Tělesné postižení určitým způsobem zabraňuje mobilitě a pracovní aktivitě. Společným znakem jedinců s tělesným postižením je omezení pohybu [26]. V souladu s Kudláčkem a Ješinou [18] se však snažíme vnímat jedince se specifickým pohybovým projevem a nezaměřujeme se na fakty, že nemohou chodit, ale hledáme cesty, jak pohybové možnosti vytvořit. Jednou z příčin omezujících schopnost pohybu jedince jsou amputace dolních či horních končetin. Sportovní protetické pomůcky v současnosti umožnuji účastnit se řady běžných pohybových aktivit. Pro zmíněná omezení hybnosti jsou vhodné zimní sporty, jakými jsou lyžování nebo sledge hokej. Současné moderní kompenzační pomůcky jako výsledek technologického pokroku významně přispívají k realizaci plnohodnotného života osob se zdravotním postižením, nabízí komprehenzivní naplnění jednotlivých aspektů významu tělovýchovy a sportu osob se zdravotním postižením jako fundamentálního základu pro vyšší kvalitu života. Ve vztahu k pohybovým aktivitám jedinců s tělesným postižením existují pomůcky, které dokáží částečně či plně nahradit funkce končetin [16]. Zimní sporty jsou oblíbenými činnostmi pro všechny věkově kategorie, vedou člověka k vyhledávání situací, kdy překovává sám sebe a získává řadu nových zážitků. Jak uvádí Kučera a Bartoňová [15], lyžování je jednou z možností, kdy i osoby s tělesným postižením mohu trávit volný čas na sněhu, často společně se svou rodinou či přáteli. Pobyt a pohyb v zimním prostředí může však být provázen jistými zdravotními riziky. Při realizaci zimních sportů osob s tělesným postižením musíme mít ve zvýšené míre na paměti princip bezpečnosti, ale i vyšší ceny sportovního náčiní a v neposlední řadě neinformovanost okolí, sportující veřejnosti [13].

\section{Sjezdové lyžování osob s tělesným postižením}

Monoski je speciální sportovní náčiní, které kompenzuje fyzický handicap tělesně postižených lyžařů - mužů i žen s míšní lézí, spastiků i osob s amputacemi dolních i horních končetin, a umožňuje jim zařadit se mezi lyžařskou veřejnost. Skládá se zjedné běžné lyže, na které je upevněna v silném vázání nosná a velmi pevná hliníková konstrukce s odlehčenou skořepinou, ve které je lyžař posazen. Ta navíc chrání dolní končetiny před úrazem i zamezuje jejich prochladnutí. Aktivní bezpečnost je doplněna použitím nastavitelného tlumiče a dle individuální potřeby lyžaře fixačními pásy, které nahrazují nefunkční svaly a udržují nehybné nohy v pozici zabezpečující nežádoucí vychýlení [1]. Konstrukce monoski umožňuje 
zdvih skořepiny do polohy vhodné pro nasedání na sedačkovou lanovku, případně může být monoski taženo na vleku staršího typu POMA či kotvě pomocí tažného zařízení s manuální pojistkou pro odpojení na konci vleku.

Kvasnička [19] uvádí, že sjezdové lyžování na monoski je mladý sport, který v posledních letech zaznamenává velký rozvoj. Díky kompenzačním pomůckám ji mohou provozovat i lidé s těžkým tělesným či kombinovaným postižením. První konstrukce monoski byly vyráběny v Německu, následně v USA a Kanadě. Pomalý rozvoj souvisel podle Hrušy [8] především s obtížnou dostupností vybavení jak zimních areálů (bezbariérový př́istup), tak i samotných lyžařuo. V současnosti se lyžování na monoski převážně realizuje formou výukových kurzo̊, propagačních akcí a některé lyžařské školy již nabízí jednotlivcům nejen odbornou pomoc, ale i potřebné vybavení. Lyžování na monoski je také provozováno v rámci výkonnostního sportu, kde respektuje pravidla Mezinárodní lyžařské federace (Fédération Internationale de Ski - FIS) s určitou specifickou úpravou a je také zařazeno mezi paralympijské sporty [9].

\section{Lyžování na monoski v České republice}

V České republice se veřejnost s monoski poprvé setkala v roce 1988 ve Špindlerově Mlýně, kde se konalo Mistrovství republiky tělesně postižených. Od roku 1992 se lyžování vozićčářò rozvíjí na Fakultě tělesné kultury Univerzity Palackého v Olomouci v Centrum aplikovaných pohybových aktivit a od roku 1994 na Fakultě tělesné výchovy a sportu Univerzity Karlovy v Praze v Centru sportovních aktivit zdravotně postižených. Postupně se zvyšuje počet organizací a instruktorů, kteří se lyžování na monoski v ČR věnují, ale poptávka je stále větší než nabídka [15]. K propagaci a šíření aktivity v současnosti přispívají platformy jako jsou Dny na monoski, činnost občanského sdružení Sportability, dále pak Centrum Paraple a několik českých sportovních subjektů (Handy Club Ostrava, SKV Praha, MONOSKI Zlín aj.). Aktuálně nejvýznamnějším subjektem na poli sjezdového lyžování osob s tělesným postižením je nezisková organizace Centrum handicapovaných lyžařù (CHL) se sídlem v Janských Lázních pracující se záštitou Svazu lyžařu ČR. Zabývá se lyžováním pro osoby s postižením již od roku 2005 a navázalo svou činností na pořádání individuálních výukových lyžařských kurzů pro vozíčkáře pořádaných již od roku 1996. Činnost této veřejně prospěšné organizace, sídlící ve světoznámých horských lázních zaměřených na pohybové ústrojí, je zaměřena především na lyžování těžce tělesně postižených převážně mladých lidí a dětí po úrazech páteře, dále pak klientům s vrozenými vadami a osobám s následky po onemocnění pohybového aparátu. Dle Pavlasové [27] se jedná o ojedinělý český komplexní projekt určený osobám s tělesným postižením, a to bez rozdílu věku. CHL zajištuje i přípravu tělesně postižených výkonnostních lyžařŭ, aktuálně je jediným pořadatelem domácích i mezinárodních závodů organizovaných v České republice pod patronací International Paralympic Committee [5]. CHL svým širokým záběrem činností, odbornými kvalitami a mnohaletými zkušenostmi výrazně pozitivně ovlivňuje proces vyrovnání se s postižením, zapojení do aktivního životního stylu a přispívá v oblasti zajištění vyšší kvality života osob s tělesným postižením v České republice.

\section{Metodika výzkumu}

Cílem výzkumu bylo zjistit vliv lyžování na monoski na kvalitu života prostřednictvím zpracování kvantitativní dat získaných dotazníkovým šetřením.

K naplnění cíle výzkumu byly formulovány následující vědecké otázky:

V01: Ovlivňuje lyžování na monoski pozitivně kvalitu života probandů?

V02: Jaká část lyžařuo se po získaném postižení (úraz) k lyžování opět s využitím monoski navrací? V03: Jaké přínosy lyžování na monoski označili respondenti za klíčové?

Metodika výzkumu byla založená na empirickém vědeckém postupu s využitím kvantitativního přístupu, který vychází z deduktivního procesu realizovaného dotazníkového průzkumu. Jeho záměrem bylo získání objektivních dat a z nich vycházejících ověřitelných a srovnatelných výsledků, interpretací a odpovědí na formulované vědecké otázky s vyslovením závěrů k doložení sledovaných skutečností.

\section{Charakteristika výběrového souboru}

Výzkumný soubor tvořilo 60 osob s tělesným postižením, aktivních účastníků kurzů lyžování na monoski, organizovaný neziskovou organizací Centrum handicapovaných lyžařů v Janských Lázních. Výběr respondentů do výzkumného souboru byl příležitostný, žádný účastník kurzu monoski účast na výzkumu neodmítl. 
Z hlediska věku se výzkumného šetření zúčastnilo 36 mužỏ a 24 žen v průměrném věku 26,19 let. Z toho 19 probandů ve věku 21-34 let (31,67 \%) - 14 mužů a 5 žen,15 probandů ve věku 16-20 let (25,00 \%) - 7 mužů a 8 žen a 11 probandů ve věku 35-45 let (18,33 \%) - 7 mužơ a 4 ženy. Z 60 respondentů bylo 26 osob (43,33 \%) z kategorie mládeže do 20 let, 11 osob bylo ve věku mladší15 let a 4 osoby starší 46 let.

Dle typu zdravotního postižení tvořily výzkumný soubor osoby s dětskou mozkovou obrnou (55 \% probandů), s poraněním míchy (21,67\%), rozštěpem (6,67\%), amputací (3,33 \%) a dále s vrozenou svalovou atrofií (1,67 \%), kombinovaným postižením (1,67 \%) a jiným typem handicapu (10 \%).

Z hlediska příčin zdravotního postižení mělo vrozenou vadu $65 \%$ probandů (39 osob, z toho 20 mužů a 19 žen), a získanou vadu 35 \% probandů (21 osob po úrazu, z toho 16 mužủ a 5 žen). Častěji uváděli získanou vadu muži (44,44 \% z celkového počtu mužů) oproti ženám (20,83 \% zapojených žen). Sjezdovému lyžování před úrazem se věnovalo celkem 17 probandů se získaným postižením z celkového počtu 21 osob.

\section{Metody sběru, zpracování a vyhodnocení výzkumných dat}

Při přípravě dotazníkového šetření bylo vycházeno z teoretických poznatků a osobních zkušeností, dotazník byl vzhledem k zaměření výzkumu vlastní konstrukce a byl respondentům administrován osobně v závěru kurzu. Před samotným sběrem dat bylo provedeno konstrukční ověření dotazníku za účelem eliminovat případné nedostatky [4], a to na vzorku dvou osob s tělesným postižením, které v minulosti kurzy na monoski absolvovaly. Na jejich reflexe bylo znění dotazníku upraveno a připraveno k terénnímu použití. Osoby, které se předvýzkumu zúčastnily, nebyly dále zařazeny do výzkumného souboru probandů výzkumu. Sběr dat proběhl v zimní sezóně 2018/19 s plánovaným úmyslem pokračování v následujících letech, což se však vzhledem k nástupu SARS-CoV-2 / Covid-19 a následné pandemické situaci a nekonání kurzů v daných zimních sezónách nepodařilo uskutečnit. Místem konání sběru dat byla základna CHL pro výukový a sportovní program lyžování na monoski v Jánských Lázních.

Celkem bylo rozdáno 65 dotazníků, plně vyplněných a vyhodnotitelných dotazníků bylo vráceno 60. Návratnost dotazníků tedy činila 92,3\%.

Data z vyplněných anonymních dotazníků byla zpracována v programu Microsoft Excel 2015 a ke zpracování zjištěných údajů byla užita deskriptivní statistika a škálování. Dle typu otázek a poskytnutých odpovědí byla určena absolutní četnost a procentuální vyjádření skutečností. U otázky vlivu monoski na kvalitu života jsme využili věkové rozlišení dle Vágnerové [35] s rozhraním mladé a střední dospělosti (35 let).

Výsledky byly zpracovány do tabulek v pořadí výzkumných otázek a věcně interpretovány.

\section{výsledky výzkumu}

Vybraná výzkumná data prezentujeme v souvislosti s cílem výzkumu, položenými vědeckými otázkami a celkovým záměrem zkoumání.

V01: Ovlivňuje lyžování na monoski pozitivně kvalitu života probandů?

Otázku vlivu lyžování na monoski na kvalitu života jsme pro bohatší dokreslení skutečnosti řešili s genderovým i věkovým odlišením.

Tab. 1 Vliv lyžování na monoski na kvalitu života osob s tělesným postižením

\begin{tabular}{|l|l|l|l|l|l|}
\hline $\begin{array}{l}\text { Ovlivňuje pozitivně } \\
\text { lyžování na monoski } \\
\text { kvalitu vašeho } \\
\text { života? }\end{array}$ & Muž & žena & pod 35 let & nad 35 let & celkem \\
\hline ano & $25(69,44 \%)$ & $21(87,50 \%)$ & $35(77,78 \%)$ & $11(73,33 \%)$ & $46(76,67 \%)$ \\
\hline spíše ano & $11(30,56 \%)$ & $3(12,50 \%)$ & $10(22,22 \%)$ & $4(26,67 \%)$ & $14(23,33 \%)$ \\
\hline nevím & 0 & 0 & 0 & 0 & 0 \\
\hline spíše ne & 0 & 0 & 0 & 0 & 0 \\
\hline ne & 0 & 0 & 0 & 0 & 0 \\
\hline celkem & $\mathbf{3 6}$ & $\mathbf{2 4}$ & $\mathbf{4 5}$ & $\mathbf{1 5}$ & $\mathbf{6 0}$ \\
\hline
\end{tabular}

Data v tab. 1 prezentují, že 69,44 \% mužů a 87,50 \% žen označilo lyžování na monoski jako pozitivně ovlivňující prvek kvality jejich života. 30,56 \% mužů a 12,50 \% žen se ke kladnému vlivu přiklání („spíše ano"). Z hlediska věkového rozdělení mezi skupinou dotázaných osob z mladší generace (do 35 let) a starší generace (nad 35 let) respondentů jsme nezaznamenali výraznější rozdíly ve výsledcích: 77,78 \% 
mladších probandů ve věku pod 35 let odpovědělo jednoznačné „ano“, 73,33 \% u starší věkové kategorie. Obecně pozitivní vliv na kvalitu života bez ohledu na pohlaví či věk jednoznačně vyjádřilo 76,67 \% a ke kladnému vlivu se přiklánělo 23,33 \% dotázaných Celkem 100 \% všech probandů považuje lyžování na monoski za významný prostředek k pozitivnímu vlivu na kvalitu svého života.

Vliv na kvalitu života dokreslují data prezentující míru důležitosti lyžování na monoski v životě sledovaných probandů:

\section{Tab. 2 Vnímání důležitosti lyžování na monoski ve svém životě}

\begin{tabular}{|l|l|l|l|}
\hline $\begin{array}{l}\text { Je pro vás monoski } \\
\text { důležité? }\end{array}$ & muž & Žena & celkem \\
\hline velmi důležité & $8(22,22 \%)$ & $12(50,00 \%)$ & $20(33,33 \%)$ \\
\hline spíše důležité & $10(27,78 \%)$ & $4(16,67 \%)$ & $14(23,33 \%)$ \\
\hline důležité & $13(36,11 \%)$ & $7(29,17 \%)$ & $20(33,33 \%)$ \\
\hline spíše nedůležité & $3(8,33 \%)$ & 0 & $3(5,00 \%)$ \\
\hline nedůležité & $2(5,56 \%)$ & $1(4,17 \%)$ & $3(5,00 \%)$ \\
\hline celkem & $\mathbf{3 6}$ & $\mathbf{2 4}$ & $\mathbf{6 0}$ \\
\hline
\end{tabular}

Z výsledků vyplývá, že plná třetina probandů (33,33 \%) považuje aktivitu na monoski pro sebe za velmi důležitou, z toho takto odpovědělo 22,22 \% dotázaných mužů a plných 50,00 \% žen. Odpověd' „spíše důležité“ označilo 23,33 \% respondentů (27,78 \% mužù a 16,67 \% žen) a 33,33 \% (36,11 \% mužủ a 29,17 \% žen) za důležité. Celkem lze tedy říci, že téměř 90 \% oslovených (s mírnou převahou žen) považuje lyžování na monoski za důležitou součást svého života. V součtu pouhých 10,00 \% dotazovaných (s mírnou převahou mužơ) odpovědělo v záporném spektru možností, po vyzkoušení lyžování na monoski v praxi osobně nepovažují danou aktivitu za zajímavou součást života.

\section{navrací? \\ v02: Jaká část lyžařủ se po získaném postižení (úraz) k lyžování opět s využitím monoski}

S údaji o počtu těch, kteří se po úrazu ke sjezdovému lyžování formou monoski navrací souvisela oblast naplnění očekávání z přechodu na jinou formu lyžování (monoski). Sjezdovému lyžování před úrazem se věnovalo celkem 17 probandů se získaným postižením, což z celkového počtu 21 osob (téměř $81 \%$ ). Pouze 4 respondenti se sjezdovému lyžování v minulosti nevěnovali a lyžování na monoski pro ně tak byla nová lyžařská zkušenost.

\section{Tab. 3 Naplnění očekávání a předchozí zkušenosti s lyžováním}

\begin{tabular}{|c|c|c|c|c|}
\hline \multicolumn{5}{|c|}{ Naplnění očekávání a předchozí zkušenosti s lyžováním } \\
\hline \multirow{2}{*}{\multicolumn{2}{|c|}{ Ano }} & \multicolumn{3}{|c|}{ Věnovali jste se lyžování před úrazem? } \\
\hline & & ne & celkem & \\
\hline \multirow{6}{*}{$\begin{array}{l}\text { Naplnilo lyžování na monoski } \\
\text { vaše očekávání? }\end{array}$} & ano & $9(52,94 \%)$ & $4(100 \%)$ & $13(61,90 \%)$ \\
\hline & spíše ano & $8(47,06 \%)$ & $\odot$ & $8(38,10 \%)$ \\
\hline & nevím & $\odot$ & 0 & $\odot$ \\
\hline & spíše ne & 0 & 0 & 0 \\
\hline & & 0 & 0 & 0 \\
\hline & celkem & 17 & 4 & 21 \\
\hline
\end{tabular}

Z prezentovaných údajů v tab. 2 lze vyvodit, že dotazovaní, kteří měli zkušenosti s lyžováním před úrazem a zapojili se po úrazu do aktivit na monoski, vyjádřili, že jim lyžování na monoski přineslo naplnění osobního očekávání z dané aktivity. Z 21 pozitivních odpovědí bylo 13 odpovědí jednoznačné „ano“ (61,90\%) a 8 odpovědí „spíše ano“ (38,10\%). Celkem 100 \% dotázaných probandů vyjádřilo spokojenost a bylo v této oblasti naplněno jejich očekávání, a to včetně těch, kteří se lyžováním začali zabývat až po úraze.

\section{V03: Jaké přínosy lyžování na monoski označili respondenti za klíčové?}

V otázce pořadí důležitosti v oblasti přínosů lyžování na monoski pro osoby s postižením respondenti sestavili pořadí možných přínosů dané pohybové aktivity podle osobní důležitosti, a to od 1-nejdůležitější až po 5 - nejméně důležitá. Hierarchicky uspořádané pořadí formulovaných přínosů lyžování 
na monoski vycházelo z pevného výběru možností, výsledné pořadí je sestaveno s využitím aritmetických průměrů ( $\mu$ ) a doplněnou o absolutní četnost výběru dané položky (X60).

\section{Tab. 4 Přínosy lyžování na monoski pro osoby s tělesným postižením}

\begin{tabular}{|l|l|c|c|}
\hline \multicolumn{1}{|c|}{ Přínosy lyžování na monoski } & $\mu$ & $X_{60}$ \\
\hline 1. & zábava a radost ze života & 1,3 & 50 \\
\hline 2. & vzrušení, pestrý život & 1,58 & 36 \\
\hline 3. & vřelé vztahy s druhými & 1,92 & 30 \\
\hline 4. & seberealizace & 2,35 & 19 \\
\hline 5. & pocit sounáležitosti & 2,53 & 15 \\
\hline 6. & pocit úspěchu & 2,58 & 12 \\
\hline 7. & samostatnost & 2,63 & 16 \\
\hline 8. & sebeúcta & 2,77 & 9 \\
\hline 9. & být v úctě & 3,18 & 7 \\
\hline
\end{tabular}

Uvedené výsledky preferencí dokládají, že probandi výzkumného šetření považují za jednoznačně nejdůležitější přínos lyžování na monoski př́ležitost k zábavě a zvýšení radosti ze života, dále pak pocity vzrušení provázející tuto pohybovou aktivitu a tím zpestření života, a možnost navázání vřelých vztahů s druhými lidmi při jejím provozování. Za méně důležité byly považována možnost seberealizace, pocit sounáležitosti či pocit úspěchu. Nejmenší přínos spatřují v oblasti samostatnosti, sebeúcty a otázce být v úctě u druhých.

\section{Diskuse}

Výsledky doložené v tab. 1 nabízí odpovědi na otázku, zda lyžování na monoski ovlivňuje pozitivně kvalitu života probandů? 69,4 \% mužů a 87,5 \% žen uvedlo, že považují aktivitu jednoznačně za pozitivní prostředek zlepšení kvality svého života, 30,6 \% mužuo a 12,5 \% žen se ke kladnému vlivu přiklonilo. S přihlédnutím na věkové hledisko není mezi mladšími (do 35 let) a staršími respondenty (nad 35 let) výraznějších rozdílů. 77,8 \% mladších probandů a 73,3 \% probandů starší věkové kategorie vyjádřilo jednoznačné „ano“. Celkem 100 \% dotázaných bez ohledu na pohlaví či věk se vyjádřilo, že lyžování na monoski má na kvalitu jejich života pozitivní vliv, přičemž u respondentů věkově starších i mladších nebo genderově diferencovaných není patrný větší rozdíl v hodnocení. Především pro vozíčkáře, kteří mají silně omezené možnosti smysluplného volnočasového vyžití na čerstvém vzduchu, se může jednat o jednu z vhodných možností aktivního trávení svého volného času v zimním období. Dle Vágnerové [35] je zdravotní postižení psychickou zátěží, kterou se musí člověk postupně učit zvládnout. Na tomto poli jsou pohybové aktivity efektivní cestou k vyhledávání důvodů k překonání nových výzev a prožívání silných emocí. To pak vzájemně úzce souvisí s nalezením a udržením si životního optimismu, což může přinášet výrazný vliv i na posilování sociálních vztahů. Jak formuluje Kábele [14], aktivním zaměřením se na oblast zvládání emocí, adaptace na zátěž, vyrovnání se s překážkami a překonávání sociálních bariér dochází k přijetí sociálních rolí a k navazování kontaktů v rámci intaktní populace. Výsledky doplňují názor Novosada [25], který chápe kvalitu života s tělesným postižením právě jako výzvu v rovině osobní a společenské. K porozumění toho, jak lyžování na monoski může jedinci s postižením pomáhat zlepšovat kvalitu života, by bylo vhodné doplnit zkoumání o kvalitativní část výzkumu formou případových studií. Názor, že pro osoby s postižením jsou pohybové aktivity jedním z důležitých prostředků celkového vnímání života, jeho kvality a hodnoty dokreslují i výsledky našeho zkoumání. Vliv na kvalitu života dokreslují data prezentující míru důležitosti lyžování na monoski v životě probandů (tab. 2), kde třetina probandů považuje aktivitu na monoski za pro sebe za „velmi důležitou“, další pozitivní odpovědi „spíše důležité“ a „důležité“ označila více, než polovina dotázaných. Celkem se tedy jedná o téměř $90 \%$ respondentů, kteří považují lyžování na monoski za podstatnou součást svého života. Ačkoli muži inklinují k aktivnějšímu způsobu trávení volného času s využitím pohybových aktivit a fyzické zátěže [32, 33, 38], z celého souboru žen se zde jedná o plných 50 \% z těch osob, které monoski považují za velmi důležitou součást svého života. Pouhých 10 \% dotazovaných s mírnou převahou mužò odpovědělo v záporném spektru možností a nepovažují danou aktivitu osobně za přínosnou. Prožitky spojené s monoski nebo jiné okolnosti pravděpodobně neodpovídaly jejich představěči aktuálním potřebám, avšak to, že se zúčastnili kurzu/ů monoski by mohlo ukazovat na zájem o aktivní život a tendenci k vyhledávání prostředků směřujících k němu. 
Další výzkumnou oblastí bylo zmapování zájmu o sjezdové lyžování u osob se získaným postižením, kteří se před úrazem předmětnou pohybovou činností zabývali. Položili jsme si otázku: Jaké množstuí lyžařů se po úrazu k lyžování formou monoski navrací? Výsledky v tab. 3 dokládají souvislost vztahu dotazovaných osob ke sjezdové lyžování před a po úrazu. Z celkového počtu osob výzkumného souboru mělo 21 probandů získané tělesné postižení. Z této skupiny jich 17 odpovědělo, že se sjezdovému lyžování věnovali již před úrazem, což činí něco málo přes 80 \% dotázaných. Tyto údaje jsou dány do souvislosti s oblastí naplnění očekávání z přechodu na jinou formu lyžování (monoski): Z 21 pozitivních odpovědí bylo 13 odpovědí jednoznačné „ano“ (61,9 \%) a 8 odpovědí „spíše ano“ (38,1 \%). Lze konstatovat, že plných 100 \% dotázaných vyjádřilo, že jim lyžování na monoski přineslo naplnění osobního očekávání, at́ se jednalo o ty, kteří se lyžování v minulosti vůbec nevěnovali, nebo o dotázané, kteří již měli zkušenosti s lyžováním před úrazem a zapojili se po úrazu do předmětné činnosti novým, pro ně alternativním způsobem (monoski). Všichni probandi se získaným postižením tak vyjádřili jednoznačnou spokojenost k provozování sjezdového lyžování na monoski, tato forma lyžování splnila jejich očekávání. Později získané postižení představuje podstatně větší psychické trauma, kdy si daná osoba zpravidla uvědomuje, co získaným postižením případně ztrácí. Návrat k činnosti vhodnou alternativou může významně napomoci v oblasti akceptace postižení a k přínosu pro kvalitu života. Tento proces je zpravidla usnadněn předchozími lyžařskými zkušenostmi, pozitivním transferem některých dovedností a schopností vnímání specifik daného pohybu na sněhu. Uplatnění některých dřivějších zkušeností a lyžařských návyků přináší výhodu při procesu osvojování techniky jízdy na monoski. V praxi se dané osoby zpravidla velmi dobře adaptují na daný pohyb, rychleji se na svahu osamostatňují a navrací se k dřivějším kladným pocitům spojeným s činností. Proces však může narušovat i výrazně odlišný charakter pohybu na lyžařském svahu. Výsledky naznačují, že přechod na novou techniku lyžařského pohybu nepůsobí negativním způsobem a alternativní forma aktivity naplňuje potřeby realizátorů. Ačkoli dle Opatřilové a Zámečníkové [26] je společným znakem jedinců s tělesným postižením dolních končetin omezení pohybu, lyžování na monoski díky moderní technologii zpracování sportovní pomůcky zde nabízí určitou kompenzaci. Jde o rozšíření možností pro aktivní život, a to navíc v zimním, jinak náročnějším a chudším období pro aktivity osob s tělesným postižením. Návrat k oblíbené aktivitě provozované před získáním vady ve spojení s naplněním určitého očekávání se může podle Jesenského [12] stát důležitým momentem v procesu vyrovnání se s postižením, ke směřování k životní spokojenosti, komfortu a k celkové psychické pohodě.

Výsledky prezentující hierarchicky uspořádané pořadí formulovaných přínosů lyžování na monoski (tab. 4) ukazují na potřebu osob s postižením vyhledávat bohatší a hodnotnější život. Za tři klíčové přínosy označili probandi výzkumného šetření příležitost $k$ zábavě a zoǵšení radosti ze života (X60=50), pocity vzrušení provázející lyžování na monoski a tím zpestření vlastního života (X60=36), a možnost pro navazování vřelých vztahů s druhými při jejím provozování (X60=30). Porovnáním těchto preferencí se závěry průzkumu Hlaváčové [17] mezi českými sledge hokejisty naznačují možný společenský posun v oblasti vyhledávaných hodnot. Nejvýznamnější postavení v průzkumu v roce 2006 měla seberealizace, která se v našem výzkumu zařadila výrazněji níže. Naše výsledky ukázaly, že možnost k seberealizaci, ale i pocit sounáležitosti či pocit úspěchu je považováno za méně důležité. Rozpor může souviset s odlišsnými cíli, kdy sledge hokejisté k účasti na dané pohybové aktivitě spíše využívají výkonovou motivací (potřeba soutěžit a podat výkon), kdežto probandi výzkumného sledování motivaci stimulační směřující k dosažení duševní pohody či neobvyklým zážitkům. Mírně překvapivé je dále umístění zájmu o vlastní samostatnost až v druhé polovině preferencí a na úplném závěru umístění sebeúcty a být v úctě od druhých. Lze předpokládat, že zjištěné skutečnosti jako hodnoty nejen majoritní, ale i minoritní společnosti, se mohou časem měnit. S probíhajícím procesem inkluze nepovažují osoby se zdravotním postižením již za důležité být zvýhodňováni a zpravidla nestojí o lítost druhých [28]. Proto možná níže umístěné přínosy a hodnoty nepovažují již za aktuálně tak důležité, jako emočně pestrý a bohatý život. To odpovídá názoru Šimka [34], že současný člověk žije především přítomností a v jeho životě mnohdy dominuje zaměření na silné prožitky.

\section{Závěry}

Výsledky našeho šetření naznačují, že lyžování na monoski pozitivně ovlivňuje kvalitu života osob s tělesným postižením. Naprostá většina probandů považuje lyžování na monoski za důležitou součást svého života. Ze skupiny dotazovaných, kteří měli zkušenosti s lyžováním před úrazem a zapojili se po úrazu do aktivit na monoski, všichni vyjádřili, že jim tato forma lyžování přinesla naplnění osobního očekávání a aktivita tak napomáhá udržet úroveň kvality předchozího života. Mezi tři klíčové přínosy 
aktivity na monoski respondenti uvedli zoýšení radosti ze života a příležitost k zábavě, zpestření života a pocity vzrušení, a navázání vřelých vztahů s druhými. Výsledky ukazují, že lyžování na monoski přispívá ke zvýšení kvality života osob s tělesným postižením, a to nejen z hlediska samotné možnosti realizace vlastní pohybové činnosti (součásti aktivního životního stylu), hodnotným prožitkům, které monoski nabízí, ale i ke zlepšení psychického zdraví a možnosti bohatších sociálních kontaktů, případně k opětovného věnování se oblíbené pohybové aktivitě v alternativní formě (monoski) v poúrazovém stavu.

\section{Reference}

[1] CHL - Centrum handicapovaných lyžařo̊ Janské Lázně (2018) [cit. 2018-11-08]. Dostupné z: http:// monoski.info/

[2] Čapková, M. (2007). Význam sportu v životě osob se zdravotním postižením. České Budějovice: Jihočeská univerzita, Zdravotně sociální fakulta, katedra klinických oborů, časopis Kontakt. [online] [cit. 2018-05-11] Dostupné z: http://casopiszsfju.zsf.jcu.cz/kontakt/administrace/clankyfile/20120327101923635778.pdf

[3] ČSÚ (2018). https://www.czso.cz/documents/10180/90600407/26000619204.pdf/fad38a0f-4641-4207-bd23-79784b88c10f?version=1.1

[4] Disman, M. (2011). Jak se vyrábí sociologická znalost. Praha: Karolinum.

[5] Dušek, M. (2018). Závěrečná zpráva pro rok 2017/2018. [online] [cit. 2019-03-02]. Dostupné z: https://www.czechski.com/userfiles/files/KHL/ZZ/Zaverecna\%20zprava\%202017-2018.pdf

[6] Francová, L. (2014). The level of physical and social skills after completion of training program for children aged 9-11. Acta Gymnica, 44(1), 33-45. https://doi.org/10.5507/ag. 20014.004

[7] Hardman, A.E. \& Stensel, D.J. (2009). Physical Aktivity and Health. New York.

[8] Hruša, J. et al. (1999). Lyžování zdravotně postižených: Česká škola lyžování. 1999. Praha: Svaz lyžařu České republiky, 1999.

[9] IPC- International Paralympic Committee: Wheelchair curling [online]. Germany [cit. 2018-11-08]. Dostupné z: https://www.paralympic.org/wheelchair-curling

[10] Janský, P. (2007). Vliv kvalifikace a pracovní uplatnitelnosti na kvalitu života zrakově postižených, zejména v oblasti jejich společenského statutu a sociální intervence. [Disertační práce]. České Budějovice: Jihočeská univerzita.

[11] Jesenský, J. (1995). Uvedení do rehabilitace zdravotně postižených. Praha: Karolinum.

[12] Jesenský, J. (2003). Zdravotně postižení - programy pro 21. století. Hradec Králové: Gaudeamus, 2003. Aktuální problémy speciální pedagogiky.

[13] Ješina, 0. (2007). Aplikované pohybové aktivity v zimní přírodě. Olomouc: Univerzita Palackého.

[14] Kábele, J. (1992). Sport vozíčkářòu. Praha: Olympia.

[15] Kučera, M. \& Bartoňová, R. (2013). Dny na monoski 2013 - Př́́klad propagace APA pro širokou veřejnost. Studia Sportiva, 3, pp. 177-184.

[16] Kudláček, M. (2012). Organizace sportu s tělesným postižením. In Janeček, Z. et al. Vybrané kapitoly ze sportu osob se zdravotní postižením. Olomouc: Univerzita Palackého.

[17] Hlaváčková, P. (2006). Sport jako prostředek integrace lidí s tělesným handicapem do společnosti. [Bakalářská práce]. Praha: Evangelická teologická fakulta.

[18] Kudláček, M. \& Ješina, O. (2013). Integrovaná tělesná výchova. Olomouc: Univerzita Palackého.

[19] Kvasnička, J. (2012). Metodika výuka lyžování na mono-ski. Olomouc: Univerzita Palackého.

[20] Lahtinen, U., Rantala, P. \& Malin, A. (2007). Physical performance of individuals With Intellectual Disability: A 30-Year Follow-Up. Adapted physical activity quarterly, 24 (2), pp. 125-143.

[21] Machalková, D. (2012). Sport zdravotně postižených. [online]. Brno, 2012 [cit. 2018-11-08]. Dostupné z: https://is.muni.cz/th/ngjeo/. Diplomová práce. Masarykova univerzita, Pedagogická fakulta.

[22] Maslow, A., H. (2014). 0 psychologii bytí. Praha: Portál.

[23] MPSV (2005). Práva tělesně postižených [online]. [cit. 2018-11-08]. Dostupné z: https://www.mpsv. $\mathrm{cz} / \mathrm{cs} / 841$

[24] MPSV (2018), Úmluva o právech osob se ZP. [cit. 2018-10-02]. Dostupné z: https://www.mpsv.cz/ files/clanky/28419/Umluva_0_pravech_osob_se_ZP.pdf

[25] Novosad, J. (2009). Poradenství pro osoby se zdravotním a sociálním znevýhodněním. Praha: Portál.

[26] Opatřilová, D. \& Zámečníková, D. (2007). Somatopedie: Texty k distančnímu vzdělávání. Brno: Paido. 
[27] Pavlasová, Š. (2019). Využití zimních sportooních aktivit pro osoby se zdravotním postižením. [Diplomová práce]. Hradec Králové: PdF UHK.

[28] Růžičková, K. (2016). Reading Rehabilitation for Individuals with Low Vision. Research and Practice in the Czech Republic. New York: Springer International Publishing.

[29] Růžičková, K. \& Růžička, I. (2011). Development of social competences in youths with a visual impairment. Annales Universitatis Paedagogicae Cracoviensis - Studia Psychologica IV, pp. 64-70.

[30] Slepička, P. et al. (2009). Psychologie sportu. Praha: Karolinum.

[31] Shapiro, R. D. \& Ulrich, A. D. (2001). Social Comparisons of Children With and Without Learning Disabilities When Evaluating Physical Competence. Adapted physical activity quarterly, 18, 273-288.

[32] Sigmund, E., Sigmundová, D., Mitáš, J., Chmelík, F., Vašíčková, J. \& Frömel, K. (2009). Variability of selected indicators of physical activity in a randomized sample of the Czech population between the years 2003-2006: Results from the short and long self administered format of the IPAQ questionnaire. Acta Universitatis Palackianae Olomucensis. Gymnica, 39(2): pp. 23-31.

[33] Suchomel, A. \& Sigmundová, D. (2011). Pohybová aktivita mužů a žen Libereckého regionu z hlediska denních činností. Tělesná kultura, 34(1): pp. 108-118.

[34] Šimek, J. (2015). Lékařská etika. Praha: Grada, 2015.

[35] Vágnerová, M. (2012). Vývojová psychologie. Praha: Portál.

[36] Vágnerová, M. (2004). Psychopatologie pro pomáhající profese. Praha: Portál.

[37] WHO (2006). Promoting Physical activities and Active Living in Urban Environments. Geneva: Author.

[38] ZDRAVÍ 2020. Národní strategie ochrany a podpory zdraví a prevence nemocí - Akční plán č. 1: Podpora pohybové aktivity na období 2015-2020. Praha: Ministerstvo zdravotnictví ČR. 